\title{
Evaluation of knowledge, attitudes, and clinical education of dental students about COVID-19 pandemic
}

\author{
Osman Ataş ${ }^{\text {Corresp., }}{ }^{1}$, Tuba Talo Yildirim ${ }^{2}$ \\ 1 Department of Pediatric Dentistry, Faculty of Dentistry, Firat University, Elazig, Turkey \\ 2 Department of Periodontology, Faculty of Dentistry, Firat University, Elazığ, Türkiye \\ Corresponding Author: Osman Ataş \\ Email address: o.atas@firat.edu.tr
}

\section{Abstract}

Background: The novel coronavirus disease (COVID-19) is a new viral respiratory illness, first identified in Wuhan province, China. Dental professionals and dental students are at an increased risk for these viruses from dental patients, as dental practice involves face-to-face communication with the patients and frequent exposure to saliva, blood, and other body fluids. Dental education can play an important role in the training of dental students, adequate knowledge and adopting attitudes regarding infection control measures. The aim of this study was to evaluate knowledge, attitudes, and clinical education of dental students about COVID-19 pandemic. Methods: A total of 355 pre-clinical and clinical dental students (242 and 113, respectively, comprising 190 females and 165 males) at FiratUniversity Dentistry Faculty, in Elazığ, Turkey answered an online questionnaire about the biosafety procedures for and their attitudes to and knowledge of COVID-19. The study was conducted in March 2020, Turkey. The data gained were analyzed using descriptive statistical methods and chi-square test. Results: Both the clinical and preclinical students were found to be afraid of infecting themselves and their environment with COVID-19, and the difference between them was statistically significant. Three quarters $(74.9 \%)$ of the participants responded yes to the question of whether they thought that experiences related to COVID-19 affected them psychologically, with the differences between gender and clinical status were statistically significant. Responses to the question of which clinical rotation worried them more were $29.9 \%$ endodontics, $25.1 \%$ oral and maxillofacial surgery, $16.3 \%$ prosthesis, $15.2 \%$ periodontology, $6.8 \%$ restorative dentistry, 3.9\% oral diagnosis and radiology, $1.7 \%$ pedodontics, and $1.1 \%$ orthodontics, with a significant difference between the preclinical and clinical students. Regarding the measures applied by the clinical students in their internships, the responses were $100 \%$ gloves and $100 \%$ mask (with $11.5 \%$ FFP3/N95 mask), $73.6 \%$ face protective shield and $37.1 \%$ safety glasses, and $49 \%$ bonnet and $16.8 \%$ disposable box, with $90.2 \%$ frequent hand washing, and $86.7 \%$ frequent hand antiseptic usage.

Conclusions: While students gave good responses regarding the standard measures they take to protect against transmission of COVID-19, their knowledge and attitudes about the extra measures they can take should be improved. For students to be least affected by fears associated with the disease, dental faculties should be ready to provide psychological services to those in need. 
2 Evaluation of knowledge, attitudes, and clinical education of dental students about COVID-19 pandemic

3 Running Title: Dental students and COVID-19

7 'Department of Pediatric Dentistry, Faculty of Dentistry, Firat University, Elazig, Turkey.

$8 \quad{ }^{2}$ Department of Periodontology, Faculty of Dentistry, Firat University, Elazig, Turkey.

11 KEYWORDS: COVID-19, dental student, attitudes, dental education

\section{CONFLICT OF INTEREST}

13 The authors declare that they have no conflicts of interest.

*Corresponding author: Osman Atas. Assistant Professor. Department of Pediatric Dentistry, Faculty of mail:osman_atas88@hotmail.com 
24 Evaluation of knowledge, attitudes, and clinical education of dental students about COVID-19 pandemic

26 Running Title: Dental Student and COVID-19

27

28

29

30

31

32

33

34

35

36

37

38

39

40

Peer] reviewing PDF | (2020:05:48683:1:1:NEW 16 Jun 2020) 


\section{Abstract}

46 Background: The novel coronavirus disease (COVID-19) is a new viral respiratory illness, first identified in

47 Wuhan province, China. Dental professionals and dental students are at an increased risk for these

48 viruses from dental patients, as dental practice involves face-to-face communication with the

49 patients and frequent exposure to saliva, blood, and other body fluids. Dental education can play

50 an important role in the training of dental students, adequate knowledge and adopting attitudes

51 regarding infection control measures. The aim of this study was to evaluate knowledge, attitudes, and

52 clinical education of dental students about COVID-19 pandemic.

53 Methods: A total of 355 pre-clinical and clinical dental students (242 and 113, respectively, comprising 190

54 females and 165 males) at FıratUniversity Dentistry Faculty, in Elazı ̆̆g, Turkey answered an online questionnaire

55 about the biosafety procedures for and their attitudes to and knowledge of COVID-19. The study was conducted

56 in March 2020, Turkey. The data gained were analyzed using descriptive statistical methods and chi-square test.

57 Results: Both the clinical and preclinical students were found to be afraid of infecting themselves and their

58 environment with COVID-19, and the difference between them was statistically significant. Three quarters

$59(74.9 \%)$ of the participants responded yes to the question of whether they thought that experiences related to

60 COVID-19 affected them psychologically, with the differences between gender and clinical status were

61 statistically significant. Responses to the question of which clinical rotation worried them more were $29.9 \%$ 
62 endodontics, $25.1 \%$ oral and maxillofacial surgery, $16.3 \%$ prosthesis, $15.2 \%$ periodontology, $6.8 \%$ restorative 63 dentistry, $3.9 \%$ oral diagnosis and radiology, $1.7 \%$ pedodontics, and $1.1 \%$ orthodontics, with a significant 64 difference between the preclinical and clinical students. Regarding the measures applied by the clinical students in 65 their internships, the responses were $100 \%$ gloves and 100\% mask (with $11.5 \%$ FFP3/N95 mask), $73.6 \%$ face 66 protective shield and $37.1 \%$ safety glasses, and $49 \%$ bonnet and $16.8 \%$ disposable box, with $90.2 \%$ frequent hand 67 washing, and $86.7 \%$ frequent hand antiseptic usage.

68 Conclusions: While students gave good responses regarding the standard measures they take to protect against 69 transmission of COVID-19, their knowledge and attitudes about the extra measures they can take should be 70 improved. For students to be least affected by fears associated with the disease, dental faculties should be ready to 71 provide psychological services to those in need.

72 KEYWORDS: COVID-19, dental students, attitudes, dental education 


\section{INTRODUCTION}

88 An outbreak of pneumonia with an unknown etiology occurred in December 2019 in Wuhan, China (Ge et al.

89 2020). A month later, scientists isolated a new coronavirus (SARS-CoV-2), which was found to cause severe

90 acute respiratory syndrome (Meng et al. 2020). The pathogen was identified as the seventh member of the

91 coronavirus family to have infected humans, and the disease it caused became known as the 2019 corona virus

92 disease, or COVID-19 (Ge et al. 2020; Peng et al. 2020a). COVID-19 created a public health problem affecting

93 not only China but the whole world. On January 31, 2020 the World Health Organization (WHO) declared

94 COVID-19 an international emergency that threatened public health. Later, the infection became much more

95 widespread, and on March 12, 2020 the WHO updated the situation, declaring COVID-19 a pandemic.

96 A coronavirus is a type of virus that can be transmitted from animals to humans; in such cases, this virus mutates

97 when it passes to humans, further leading to human-to-human spread (Chan et al. 2020b).(Chan et al. 2020b) A

98 coronavirus can progress in different stages, such as mild, moderate, and severe, and such viruses are in the same

99 group as Severe Acute Respiratory Syndrome (SARS) of 2002 and Middle East Respiratory Syndrome (MERS) of

1002012 (Huang et al. 2020). The new coronavirus is generally a disease that manifests in symptoms of high fever

101 and cough, and in advanced cases, patients may endure respiratory distress. In addition, it has been shown that

102 different symptoms such as nausea, vomiting, diarrhea, muscle-joint pain, and loss of appetite may occur. In

103 severe cases, pneumonia, severe respiratory failure, kidney failure, and death may occur (Sabino-Silva et al. 
104 2020a). A coronavirus is a type of virus that can be transmitted from animals to humans; in such cases, this virus

105 mutates when it passes to humans, further leading to human-to-human spread (Phan et al. 2020).

106

107

108 COVID-19 is detected in the saliva of infected patients, so dental/oral and other healthcare professionals in

109 particular should be very careful in protecting against the spread of the disease (Sabino-Silva et al. 2020b; To et

110 al. 2020). Transmission is similar to other respiratory diseases; it can occur with droplets ejected during speaking,

111 coughing, or sneezing (activities of the respiratory system) and also through aerosols employed during clinical

112 procedures (Sabino-Silva et al. 2020b).

113 In this process, dentists may provide routes for virus transmission from unrecognized COVID-19-infected patients

114 and patients under surveillance. It appears possible to have asymptomatic infections. Thus, the contamination

115 may occur before symptoms of the disease appear. Relatedly, a recent clinical study showed that $29 \%$ of 138

116 COVID-19 patients hospitalized in Wuhan, China were healthcare professionals (Chan et al. 2020a).

117 Routine dental practices that emit aerosols pose a risk to patients, dentists, and auxillary staff (Sabino-Silva et al.

118 2020b). As with bronchoscopy, using aerosols during dental treatments may constitute a high-risk procedure for

119 these people in respect of the inhalation of airborne particles, ocular transmission, causing them to be directly

120 exposed to the virus (Leonard et al.).

121 Therefore, dentists and dental students need to be very careful and showed develop preventive strategies to avoid

122 COVID-19 involving, for example, hand hygiene, personal protective equipment (PPE) and cross contamination

123 prevention methody for all staff when performing aerosol-emitting procedures. It is inevitable that dentistry

124 faculty students with insufficient clinical experience will be more exposed to infectious diseases.(Stewardson et 
125 al. 2002) In previous studies, occupational exposure to infective diseases in dental faculties has been reported as

126 66-80\% (Kennedy \& Hasler 1999; Stewardson et al. 2002).

127 In order to increase the compliance of dental students with universal precautions and to eliminate their 128 deficiencies, students understanding and behavior should be determined. In this study, students in dental school 129 setting were questioned in order to evaluate their general knowledge levels, attitudes, and practices in regard to 130 COVID-19.

\section{MATERIAL AND METHODS}

132 The cross-sectional study was conducted at the Faculty of Dentistry at Firat University in March 2020, during the 133 week after the first reported COVID-19 cases in Turkey. The participants were pre-doctoral dental students 134 performing their preclinical education (first, second, and third classes) and clinical rotations (fourth and fifth 135 classes). An online questionnaire was developed in Google Forms ( Elazig, Turkey) containing 17 questions about 136 the students' knowledge, attitudes, and practices of pre-doctoral students in respect of this new disease COVID137 19. The study was approved by Institu Review Board of the Firat University (2020/30-06). All participants 138 voluntarily participated in this study. Participants were informed about the nature of the study. The IRB did not 139 request written informed consent form due to being a cross-sectional study where no personal identifiers were 140 used. Prepared e-survey forms were sent to students via a link created for the purpose. It was explained at the 141 beginning of the questionnaire that the purpose of the data collection was for scientific research. From the total 142 number of 363 students in the dental school, 355 completed the whole questionnaire (response rate 97.7\%). When

143 we conducted this questionnaire (the first week of the pandemic in Turkey), the students continued their 144 education. With increased COVID-19 outbreak in Turkey, education was interrupted temporarily.

145 Since there was no known study on dentistry students concerning COVID-19, studies related to infectious diseases 146 were used to create the survey (Alharbi et al. 2019; Lorosa et al. 2019; Myers et al. 2012). We prepared the 
147 questions in three parts. In the first part, the participants were asked to supply demographic data (Course period,

148 gender); in the second part, questions were asked about attitudes and knowledge (e.g.,the fear of infecting

149 themselves or their environment while treating someone with COVID-19, on which internship worried them more,

150 and on whether antibiotics are beneficial in COVID-19 treatment); and in the third part, questions were asked

151 about biosafety procedures applied for COVID-19 (e.g., individual and infection control precation).

\section{Data analysis}

153 SPSS 21.0 for Windows was used to make a statistical analysis of the data. Descriptive statistical methods and a

154 chi-square test were employed. The significance level was set at $p<0.05$.

\section{RESULTS}

Of the 355 students, 190 (53.6\%) were female and 165 (46.4\%) were male; 242 (68.1\%) were first, second, and third grade students doing their preclinical education, and 113 (31.9\%) were fourth and fifth year students doing their clinical rotations (Table 1).

Table 2 shows the knowledge and attitudes towards COVID-19 as shown by their questionnaire responses. In respect of COVID-19 treatment, $80 \%$ of participants responded "no" to the question of whether antibiotics are beneficial, because COVID-19 is a viral infections and antibiotics may only benifical serious co-infections status. There were no significant differences in terms of gender or clinical-versus-preclinical students for these questions.

A quarter (25.1\%) responded yes to the question of whether a lecture or seminar-like information had been given in their school about COVID-19. The difference between preclinical students (19.8\%) and clinical students $(36.3 \%)$ was statistically significant $(\mathrm{p}=0.01)$ (Table 2$)$. Figure 1 shows the sources of information about the

167 disease and virus. To the question of where they gained information about COVID-19, 75.8\% indicated the 168 websites or social media accounts of professional organizations, such as the Ministry of Health, Dental 
169 Association, and WHO, 21.9\% gave information meetings held in institutions, 29.2\% gave published scientific 170 articles, 41.4\% physicians' individual websites or social media accounts, $60.1 \%$ social media accounts, like 171 Instagram, Facebook, and Twitter, 64.8\%, television and radio programs, and 65.3\% communication groups, such 172 as Whatsapp or Line.

173 The question about whether their experiences related to COVID-19 affected them psychologically received "yes" 174 response from the majority $(74.9 \%)$ of participants. The difference between females $(80.5 \%)$ and males $(68.5 \%)$ 175 was statistically significant $(\mathrm{p}=0.02)$; the difference between preclinical students $(70.2 \%)$ and clinical students $176(85 \%)$ was also statistically significant $(\mathrm{p}=0.01)$ (Table2).

177 To the question about whether they were afraid of being infected by the COVID-19 virus since they were entering 178 a profession that works very closely with other healthcare workers and patients: total of $82.3 \%$ of the participants 179 responded "yes". For males, this figure was $74.5 \%$ and for females $88.9 \%$, a statistically significant difference 180 ( $\mathrm{p}=0.001)$; for preclinical students, it was $77.6 \%$ and clinical students $92 \%$, again, a statistically significant 181 difference $(\mathrm{p}=0.002)$ (Table 2).

182 To the question of whether they were afraid of infecting relatives or people around them with the COVID-19 virus 183 because of their profession: 93.0\% of the participants responded "yes". There was no significant difference by 184 gender. Hence the difference between the preclinical (90.5\%) and clinical (98.2\%) students was statistically 185 significant $(\mathrm{p}=0.012)$. A total of $44.2 \%$ of the participants replied "yes" to the question of whether they would 186 hesitate to treat a patient who came to dental treatment after recovery from COVID-19 infection, comprising 50\% 187 of the females and $37.6 \%$ of the males, which was statistically significant $(\mathrm{p}=0.001)$. The difference between 188 preclinical (40\%) and clinical (53\%) students for this measure was not significant $(\mathrm{p}=0.066)$ (Table 2). measures related to contamination of their patients. $77.6 \%$ of females responded "yes" and $88.9 \%$ of males 
191 responded "yes", which was statistically significant $(\mathrm{p}=0.012)$. The proportion for preclinical students was $80.2 \%$

192 and for clinical students $91.2 \%$, which also constituted a significant difference $(\mathrm{p}=0.033)$ (Table 2$)$.

193 In the wake of the onset of the COVID-19 pandemic, 74.7\% of the participants responded "no" to the question if 194 they regretted having chosen the dentistry profession. There was no significant gender or preclinical and clinical 195 student difference $(\mathrm{p}=0.426, \mathrm{p}=0.382)$ (Table 2$)$.

196 Table 3 demonstrate that the students' concern about which clinical rotation are more dangerous for Covid 19

197 contamintation. Regarding the internship that worried participants most, $29.9 \%$ gave endodontics as their answer, $19825.1 \%$ oral and maxillofacial surgery, $16.3 \%$ prosthesis, $15.2 \%$ periodontology, $6.8 \%$ restorative dentistry, $3.9 \%$ 199 oral diagnosis and radiology, $1.7 \%$ pedodontics, and $1.1 \%$ orthodontics. There was a significant difference 200 between the preclinical and clinical students $(\mathrm{p}=0.001)$.

201 Figure 2 shows the individual measures taken by students against COVID-19. To the question of which individual 202 measures they were taking against COVID-19, the wearing of gloves and of a mask received responses of 33.8\% and 44.4\%, respectively; frequent hand-washing was $93 \%$ and use of cologne, wet wipes, and hand disinfectant 84.9\%; not entering public areas was 93.3\%, not having physical contact (handshaking, kissing, etc.) 88.8\%, and frequent ventilation of the environment $78.2 \%$, while changing clothes and taking a shower upon arrival home were $65.3 \%$ and $33.2 \%$, respectively; $2.7 \%$ of the respondents indicated that they did not do anything extra.

Figure 3 shows the precautions taken by clinical students for themselves in internships. These participants responded to the above question on which measures they were taking in the following proportions - use of gloves: 100\%, mask: $100 \%$, ffp $3 / \mathrm{n} 95$ mask: $11.5 \%$, face protective shield: $73.6 \%$, safety glasses: $37.1 \%$, bone: $49 \%$,

210 disposable box: $16.8 \%$, frequent hand-washing: $90.2 \%$, and frequent hand antiseptic: $86.7 \%$.

211 Figure 4 shows the precautions taken by clinical students regarding COVID-19 with the patient during dental 212 treatment. To the question of which measures for COVID-19 they were taking in this situation, the responses were 
213 as follows. Before the procedure, 73.4\% asked whether the patient had symptoms, such as fever, cough, or

214 shortness of breath, $14.2 \%$ measured the patient's fever, $15.9 \%$ applied a rubber dam, $17.7 \%$ rinsed the mouth

215 with a mouthwash containing chlorhexidin, 1.77\% rinsed the mouth with a mouthwash containing $1 \%$ hydrogen

216 peroxide content, $42.4 \%$ used a strong saliva absorber during the procedure, $12.3 \%$ avoided aerosols and

217 processes that would create droplets, preferring to use hand tools instead of an aerator, cavitron, or micromotor,

$21824.7 \%$ postponed appointments of potentially infected patients for at least 14 days, and $8.8 \%$ stated that they did 219 nothing.

\section{DISCUSSION}

221 Dentists, dental students, and auxillary staff are at more risk of encountering pathogens transmitted through blood 222 or other body fluids than the normal population (Al-Maweri et al. 2015). The key to reducing and preventing 223 contamination of various microorganisms is strict adherence to infection control procedures. Thus, the knowledge 224 about and attitudes towards infectious diseases of students who have started patient treatment procedures in the 225 clinic are very important. Less experienced students are likely to be more susceptible to the risk of infection 226 diseases (Singh \& Purohit 2011).

227 There are many studies investigating the knowledge levels and attitudes of dental students about infectious 228 diseases (Al-Maweri et al. 2015; Al-Shamiri et al. 2018; Alharbi et al. 2019; Karcioglu 2020; Lorosa et al. 2019; 229 Myers et al. 2012). COVID-19 is a very new disease that has spread rapidly and about which information is 230 limited. To our knowledge, no study has yet been made related to COVID-19 and dental students. This study 231 investigated the knowledge, attitudes and practices regarding COVID-19 of preclinical and clinical dental students 232 at Firat University, Turkey.

233 COVID-19 transmission routes are through direct contact and airborne droplets, including aerosol delivery.(Ge et 234 al. 2020) Most of the treatments in dentistry produces droplets and/or aerosols that can cause infection. Students, 
235 especially those with limited clinical experience, should be very careful about infectious diseases, to protect

236 themselves and for their patients and the employees. To prevent cross-infection in dentistry, standard measures

237 should be taken such as disposable surgical cap, disposable surgical mask, white coat, safety glasses or face

238 protection, use of disposable latex or nitrile gloves (Peng et al. 2020b). In the treatment procedures of patients, the

239 use of mouthwash (1\% hydrogen peroxide or $0.2 \%$ povidone iodine), use of "rubber-dam" (performing dental

240 practice with hand tools in a way that does not create an aerosol in conditions where it is not possible to use

241 "rubber-dam") is recommended (Samaranayake \& Peiris 2004). The use of rubber dam results in a

242 significant reduction in the microbial content of air turbine aerosols produced during operative

243 procedures, thereby reducing the risk of cross-infection in the dental practice (Ahmad 2009). It

244 is also recommended to avoid splashing or aerosole processes using extra traction measures such as the use of a

245 high-traction saliva absorber and, if possible, the use of an aerator with an anti-retraction valve (Samaranayake \&

246 Peiris 2004). Strict disinfection measures should be taken in clinics, the environment should be ventilated after

247 treatment, and the areas of contact (unit, reflector ..) should be disinfected (Peng et al. 2020b).

248 In this study, $74.9 \%$ of the students reported that there was no course approved or seminar-like information about

249 COVID-19 provided in their school. As COVID-19 very quickly became a pandemic, one may suggest that dental

250 schools may provide extra informative about this disease in their approved curriculum. Some three quarters

$251(75.8 \%)$ of the participants had received information about COVID-19 from the websites or social media accounts

252 of professional organizations, such as the Ministry of Health, the Dental Association, and the WHO, with a fifth

$253(21.8 \%)$ gaining information from meetings in institutions. In previous studies, the most important information

254 source for students was those of mass communication (television, newspapers, and magazines) (Gökengin et al.

255 2003; Opt \& Loffredo 2004; Ungan \& Yaman 2003). Nowadays, we can easily argue that social media accounts

256 have replaced the mass media. The experience we have acquired with COVID-19 suggests that after outbreaks 
257 and with the emergence of an epidemic, school administrations should definitely hold lectures and/or informative 258 meetings for their students. The awareness of students regarding scientific articles should be increased.

259 In this study, $80 \%$ of students stated that antibiotics would not be useful in COVID-19 treatment, presumably 260 because they knew that it is a viral disorder. While this $80 \%$ rate was satisfactory, we think that it should have 261 been higher.

262 Only $11.5 \%$ of the clinical students asked their patients if they were treated in the last three months and if they had 263 a high fever or dry cough or traveled abroad. This indicates a need to inform students as soon as possible about 264 diseases following outbreaks and for them to provide the necessary information in their history.

265 To the question on whether COVID-19 affected them in a negative way psychologically, according to the 266 participants responses a difference between females (80.5\%) and males $(68.5 \%)$ that was statistically significant 267 ( $\mathrm{p}=0.02)$. In a study conducted at a medical school in China, it was shown that the psychological status of female 268 and male students there was similarly affected by the COVID-19 outbreak (Cao et al. 2020). Physiological sensations related to stress, social phobia, depression, panic and fear are widespread in women, and these may be related to anxiety. It may be said that women are more negatively affected by the stressful periods than men and that anxiety is positively related to this psychological condition (Yildirim et al. 2017). Already, under normal conditions, it has been shown in many studies that female dental students are more stressed than their male counterparts. The reason for this situation is thought to be related to the fact that women feel stress more intensely in general while men hide their anxiety (Divaris et al. 2013; Jowkar et al. 2020). Further, there were differences between the proportions of preclinical and clinical students who thought that the disease had a negative psychological impact (70.2\% and 85\%, respectively). They were afraid of being infected with COVID-19 (77.6\% and $92 \%$, respectively), which were statistically significant ( $\mathrm{p}=0.02$ and $\mathrm{p}=0.04$, respectively). The majority of the participants (93.0\%) responded " yes" to the question of whether they were afraid of infecting someone around 
280 statistically significant $(\mathrm{p}=0.012)$. These results may be explained by the fact that clinical students are in contact

281 with patients during dental treatment and so the risk of infection transmission is higher for clinical than for

282 preclinical students. Dental clinical students have increasing patient contact during their education and clinical

283 years which may put them in an increased risk of cross infections (Milward \& Cooper 2007).

284 To the question of whether they would hesitate to give dental treatment to a patient who had COVID-19: 44.2\% of 285 the participants responded "yes", 36.6\% responded "no" and 19.2\% responded undecided.

286 Studies have shown that as the knowledge level of dentistry faculty students increases, so does their willingness to 287 treat patients with infectious diseases (Aggarwal \& Panat 2013; Sadeghi \& Hakimi 2009). Prejudice against such 288 patients in respect of COVID-19 may be prevented by providing students with appropriate clinical rotation. N95 mask should be used in addition to standard measures during emergency dental procedures for the person who has infection suppression or infected. Surgical masks are primarily used to stop the wearer from spreading microbes while coughing, sneezing or talking. The most important difference between respirators and surgical masks that they do not have a tight seal due to the gaps in the surgical masks. When it comes to infection control in the field of health, N95 masks with particle filters are preferred.These include three layers, being hypoallergenic, forming a liquid barrier, being tear resistant, and providing $99 \%$ bacteria and 95\% particle filtration (Ahmad 2009). about endodontics $(40.7 \%)$, prosthetics $(23 \%)$, and periodontology $(16.8 \%)$ while pre-clinical students were most concerned about oral and maxillofacial surgery (35\%), endodontics $(24.7 \%)$, and periodontology (14.5\%). We think that this is due to the better awareness of clinical students about aerosols and droplets. Infected children with 
302 For the question about, after the COVID-19 pandemic, students were more careful in their standard measures

303 regarding patient contamination, the majority (83.7\%) of participants responded "yes". COVID-19 appears to

304 have increased the awareness of students of the risks of infectious diseases.

305 Three quarters (74.7\%) of participants in the study responded "no" to the question of whether they regretted

306 having chosen dentistry. This result may be explained by the assessment that as student knowledge about

307 infectious diseases increases, such regrets become meaningless.

308 Many individual measures were taken by students in daily life related to COVID-19, the foremost among which 309 were not entering public areas (93.3\%), frequent hand-washing (93\%), avoiding physical contact $(88.8 \%)$, and 310 antiseptic use (84.9\%). It is understood that these students were conscious of the individual measures they should 311 take.

312 In respect of the results gained from questions on the precautions taken in internships and measures taken by

313 students for their patients regarding COVID-19, the clinical students were found to be very careful about standard

314 measures but less concerned about extra measures to be taken. This was probably due to their rotations in the 315 week after the first cases in Turkey was reported.

\section{CONCLUSION}

317 Dental students are inherently at high risk of exposure to infectious diseases. The emergence of COVID-19 318 brought new challenges and responsibilities to institutions providing dental education. In particular, students 319 should be informed that special measures should be taken for asymptomatic carrier patients in addition to the 320 standard measures. During the preclinical years, the knowledge of the students and appropriate attitudes to 321 infectious diseases, especially pandemics, should be developed. This is extremely important in the fight against 322 infectious diseases.

\section{CONFLICT OF INTEREST}


324 Authors declare no conflict of interest.

325

326

327

328

329

330

331

332

333

334

335

\section{REFERENCES}

336

337

338

339

340

341

342

343

344

345

346

347

348

349

350
Aggarwal A, and Panat SR. 2013. Knowledge, attitude, and behavior in managing patients with HIV/AIDS among a group of Indian dental students. Journal of dental education 77:1209-1217.

Ahmad IA. 2009. Rubber dam usage for endodontic treatment: a review. Int Endod J 42:963-972. 10.1111/j.13652591.2009.01623.x

Al-Maweri SA, Tarakji B, Shugaa-Addin B, Al-Shamiri HM, Alaizari NA, and AlMasri O. 2015. Infection control: Knowledge and compliance among Saudi undergraduate dental students. GMS hygiene and infection control 10.

Al-Shamiri H-M, AlShalawi F-E, AlJumah T-M, AlHarthi M-M, AlAli E-M, and AlHarthi H-M. 2018. Knowledge, attitude and practice of hepatitis B virus infection among dental students and interns in Saudi Arabia. J Clin Exp Dent 10:e54.

Alharbi G, Shono N, Alballaa L, and Aloufi A. 2019. Knowledge, attitude and compliance of infection control guidelines among dental faculty members and students in KSU. BMC Oral Health 19:7.

Cao W, Fang Z, Hou G, Han M, Xu X, Dong J, and Zheng J. 2020. The psychological impact of the COVID-19 epidemic on college students in China. Psychiatry Research:112934. 
Chan JF-W, Yuan S, Kok K-H, To KK-W, Chu H, Yang J, Xing F, Liu J, Yip CC-Y, and Poon RW-S. 2020a. A familial cluster of pneumonia associated with the 2019 novel coronavirus indicating person-to-person transmission: a study of a family cluster. The Lancet 395:514-523.

Chan JF, Yuan S, Kok KH, To KK, Chu H, Yang J, Xing F, Liu J, Yip CC, Poon RW, Tsoi HW, Lo SK, Chan KH, Poon VK, Chan WM, Ip JD, Cai JP, Cheng VC, Chen H, Hui CK, and Yuen KY. 2020b. A familial cluster of pneumonia associated with the 2019 novel coronavirus indicating person-to-person transmission: a study of a family cluster. Lancet 395:514-523. 10.1016/s0140-6736(20)30154-9

Divaris K, Mafla AC, Villa-Torres L, Sánchez-Molina M, Gallego-Gómez CL, Vélez-Jaramillo LF, TamayoCardona JA, Pérez-Cepeda D, Vergara-Mercado ML, and Simancas-Pallares MÁ. 2013. Psychological distress and its correlates among dental students: a survey of 17 Colombian dental schools. BMC medical education 13:91.

Ge Z-y, Yang L-m, Xia J-j, Fu X-h, and Zhang Y-z. 2020. Possible aerosol transmission of COVID-19 and special precautions in dentistry. Journal of Zhejiang University-SCIENCE B:1-8.

Gökengin D, Yamazhan T, Özkaya D, Aytuğ S, Ertem E, Arda B, and Serter D. 2003. Sexual knowledge, attitudes, and risk behaviors of students in Turkey. Journal of school health 73:258-263.

Huang C, Wang Y, Li X, Ren L, Zhao J, Hu Y, Zhang L, Fan G, Xu J, Gu X, Cheng Z, Yu T, Xia J, Wei Y, Wu W, Xie X, Yin W, Li H, Liu M, Xiao Y, Gao H, Guo L, Xie J, Wang G, Jiang R, Gao Z, Jin Q, Wang J, and Cao B. 2020. Clinical features of patients infected with 2019 novel coronavirus in Wuhan, China. Lancet 395:497-506. 10.1016/s0140-6736(20)30183-5

Jowkar Z, Masoumi M, and Mahmoodian H. 2020. Psychological Stress and Stressors Among Clinical Dental Students at Shiraz School of Dentistry, Iran. Advances in Medical Education and Practice 11:113.

Karcilioglu Ö. 2020. What is Coronaviruses, and how can we protect ourselves? Anka Tip Dergisi 2:66-71.

Kennedy J, and Hasler J. 1999. Exposures to blood and body fluids among dental school-based dental health care workers. Journal of dental education 63:464-469.

Leonard S, Volakis L, DeBellis R, PharmD FCCP K, Mayar S, and Dungan I. 2020. Transmission Assessment Report. Zhonghua Jie He He Hu Xi Za Zhi 43:199-202. 10.3760/cma.j.issn.1001-0939.2020.03.012

Lorosa AH, Pereira CM, Hussne RP, and Silva-Boghossian CM. 2019. Evaluation of dental students' knowledge and patient care towards HIV/AIDS individuals. European Journal of Dental Education 23:212-219.

Meng L, Hua F, and Bian Z. 2020. Coronavirus Disease 2019 (COVID-19): Emerging and Future Challenges for Dental and Oral Medicine. J Dent Res:0022034520914246.

Milward MR, and Cooper PR. 2007. Competency assessment for infection control in the undergraduate dental curriculum. European Journal of Dental Education 11:148-154.

Myers JE, Myers R, Wheat ME, and Yin MT. 2012. Dental students and bloodborne pathogens: occupational exposures, knowledge, and attitudes. Journal of dental education 76:479-486.

Opt SK, and Loffredo DA. 2004. College students and HIV/AIDS: More insights on knowledge, testing, and sexual practices. The Journal of psychology 138:389-403.

Peng X, Xu X, Li Y, Cheng L, Zhou X, and Ren B. 2020a. Transmission routes of 2019-nCoV and controls in dental practice. International Journal of Oral Science 12:1-6.

Peng X, Xu X, Li Y, Cheng L, Zhou X, and Ren B. 2020b. Transmission routes of 2019-nCoV and controls in dental practice. 12:9. 10.1038/s41368-020-0075-9

Phan LT, Nguyen TV, Luong QC, Nguyen TV, Nguyen HT, Le HQ, Nguyen TT, Cao TM, and Pham QD. 2020. Importation and Human-to-Human Transmission of a Novel Coronavirus in Vietnam. 382:872-874. 10.1056/NEJMc2001272

Sabino-Silva R, Jardim ACG, and Siqueira WL. 2020a. Coronavirus COVID-19 impacts to dentistry and potential salivary diagnosis. Clin Oral Investig 24:1619-1621. 10.1007/s00784-020-03248-x

Peer) reviewing PDF | (2020:05:48683:1:1:NEW 16 Jun 2020) 
396

Sadeghi M, and Hakimi H. 2009. Iranian dental students' knowledge of and attitudes towards HIV/AIDS patients. Journal of dental education 73:740-745.

Samaranayake LP, and Peiris M. 2004. Severe acute respiratory syndrome and dentistry: a retrospective view. $J$ Am Dent Assoc 135:1292-1302. 10.14219/jada.archive.2004.0405

Singh A, and Purohit B. 2011. Knowledge, attitude and practice towards infection control measures and it's correlation among dental students in Bhopal city, Central India. International Journal of Infection Control 7.

Stewardson D, Palenik C, McHugh E, and Burke F. 2002. Occupational exposures occurring in students in a UK dental school 1. European Journal of Dental Education 6:104-113.

Sun D, Li H, Lu X-X, Xiao H, Ren J, Zhang F-R, and Liu Z-S. 2020. Clinical features of severe pediatric patients with coronavirus disease 2019 in Wuhan: a single center's observational study. World Journal of Pediatrics:1-9.

To KK-W, Tsang OT-Y, Yip CC-Y, Chan K-H, Wu T-C, Chan JM-C, Leung W-S, Chik TS-H, Choi CY-C, and Kandamby DH. 2020. Consistent detection of 2019 novel coronavirus in saliva. Clinical infectious diseases: an official publication of the Infectious Diseases Society of America.

Ungan M, and Yaman H. 2003. AIDS knowledge and educational needs of technical university students in Turkey. Patient Education and Counseling 51:163-167.

Yildirim TT, Dundar S, Bozoglan A, Karaman T, Dildes N, Kaya FA, Altintas E, Oztekin F, Atas O, and Alan H. 2017. Is there a relation between dental anxiety, fear and general psychological status? PeerJ 5:e2978.

(1)

6

(1)

8


428 FIGURE LEGEND

429 Figure 1: Sources about information about COVID-19

430 Figure 2: Individual measures taken by dental students against COVID-19 in their daily lives

431 Figure 3: Precautions taken by clinical students for themselves in internships related to COVID-19

432 Figure 4: Precautions taken with the patient regarding COVID-19 while treating teeth 


\section{Table $\mathbf{1}$ (on next page)}

Table 1

Table 1: Distribution of the students according to gender and course period 
1

2 Table 1: Distribution of the students according to gender and course period

3

4

\begin{tabular}{|l|l|l|l|l|}
\hline Students & & N & $(\mathbf{\%})$ & N \\
\hline \multirow{2}{*}{ Gender } & Male & 165 & $(46.4 \%)$ & \\
\cline { 2 - 5 } & Female & 190 & $(53.6 \%)$ & $355(100 \%)$ \\
\hline \multirow{2}{*}{$\begin{array}{l}\text { Course } \\
\text { period }\end{array}$} & Clinical & 113 & $(31.9 \%)$ & $355(100 \%)$ \\
\cline { 2 - 5 } & Preclinical & 242 & $(68.1 \%)$ & \\
\hline
\end{tabular}

5

6

7

8

9

10

11

12

13

14

15

16

17

18

19

20

21

22

23

24

25

26

27

28

29

30

31

32

33

34

35

36

37

38 
39

40

41

Peer] reviewing PDF | (2020:05:48683:1:1:NEW 16 Jun 2020) 


\section{Table 2 (on next page)}

Table 2

Knowledge and attitudes of students about COVID-19 
4 Table 2: Knowledge and attitudes of students about COVID-19

\begin{tabular}{|c|c|c|c|c|c|c|c|}
\hline \multicolumn{2}{|l|}{ Questions } & \multirow{2}{*}{$\begin{array}{l}\text { Male } \\
(\mathrm{n}=165) \\
\% \\
25.5 \% \\
74.5 \%\end{array}$} & \multirow{2}{*}{$\begin{array}{c}\text { Female } \\
(\mathrm{n}=190) \\
\% \\
24.7 \% \\
75.3 \%\end{array}$} & \multirow{2}{*}{$\begin{array}{l}\mathrm{P} \\
\text { value } \\
.486\end{array}$} & \multirow{2}{*}{$\begin{array}{l}\text { Preclinical } \\
(\mathrm{n}=242) \\
\% \\
19.8 \% \\
80.2 \%\end{array}$} & \multirow{2}{*}{$\begin{array}{c}\text { Clinical } \\
(\mathrm{n}=113) \\
\% \\
36.3 \% \\
63.7 \%\end{array}$} & \multirow{2}{*}{$\begin{array}{l}\mathrm{P} \\
\text { value } \\
.001^{*}\end{array}$} \\
\hline $\begin{array}{l}\text { Have you been } \\
\text { informed about } \\
\text { COVID-19 in your } \\
\text { faculty like lectures or } \\
\text { seminars? }\end{array}$ & $\begin{array}{l}\text { Yes } \\
\text { No }\end{array}$ & & & & & & \\
\hline $\begin{array}{l}\text { Have you asked } \\
\text { questions such as high } \\
\text { fever, dry cough or } \\
\text { travel abroad while } \\
\text { taking an anamnesis } \\
\text { from your patients in } \\
\text { the last } 3 \text { months? }\end{array}$ & $\begin{array}{l}\text { Yes } \\
\text { No }\end{array}$ & $\begin{array}{l}13.9 \% \\
86.1 \%\end{array}$ & $\begin{array}{l}16.8 \% \\
83.2 \%\end{array}$ & .273 & $\begin{array}{l}17.4 \% \\
82.6 \%\end{array}$ & $\begin{array}{l}11.5 \% \\
88.5 \%\end{array}$ & .102 \\
\hline $\begin{array}{l}\text { Did COVID-19 } \\
\text { negatively affect your } \\
\text { psychology? }\end{array}$ & $\begin{array}{l}\text { Yes } \\
\text { No } \\
\text { Undecided }\end{array}$ & $\begin{array}{l}68.5 \% \\
19.4 \% \\
12.1 \%\end{array}$ & $\begin{array}{l}80.5 \% \\
6.8 \% \\
12.6 \%\end{array}$ & $.002 *$ & $\begin{array}{l}70.2 \% \\
13.2 \% \\
16.6 \%\end{array}$ & $\begin{array}{l}85 \% \\
11.5 \% \\
3.5 \%\end{array}$ & $.001 *$ \\
\hline $\begin{array}{l}\text { Are you afraid of } \\
\text { becoming infected with } \\
\text { COVID-19 as a } \\
\text { healthcare professional } \\
\text { working at close range } \\
\text { with the patient? }\end{array}$ & $\begin{array}{l}\text { Yes } \\
\text { No } \\
\text { Undecided }\end{array}$ & $\begin{array}{l}74.5 \% \\
15.2 \% \\
10.3 \%\end{array}$ & $\begin{array}{l}88.9 \% \\
5.3 \% \\
5.8 \%\end{array}$ & $.001 *$ & $\begin{array}{l}77.6 \% \\
12 \% \\
10.4 \%\end{array}$ & $\begin{array}{r}92 \% \\
5.3 \% \\
2.7 \%\end{array}$ & $.002 *$ \\
\hline $\begin{array}{l}\text { Are you afraid to infect } \\
\text { any relatives or people } \\
\text { around you in terms of } \\
\text { COVID-19 because you } \\
\text { are a healthcare worker } \\
\text { working very close to } \\
\text { the patient? }\end{array}$ & $\begin{array}{l}\text { Yes } \\
\text { No } \\
\text { Undecided }\end{array}$ & $\begin{array}{l}91.6 \% \\
4.2 \% \\
4.2 \%\end{array}$ & $\begin{array}{l}94.2 \% \\
3.7 \% \\
2.1 \%\end{array}$ & .485 & $\begin{array}{l}90.5 \% \\
5.4 \% \\
4.1 \%\end{array}$ & $\begin{array}{l}98.2 \% \\
0.9 \% \\
0.9 \%\end{array}$ & $.012 *$ \\
\hline $\begin{array}{l}\text { Would you hesitate to } \\
\text { treat a patient who came } \\
\text { to dental treatment after } \\
\text { getting over and } \\
\text { recovering from } \\
\text { COVID-19 infection? }\end{array}$ & $\begin{array}{l}\text { Yes } \\
\text { No } \\
\text { Undecided }\end{array}$ & $\begin{array}{l}37.6 \% \\
47.2 \% \\
15.2 \%\end{array}$ & $\begin{array}{l}50 \% \\
27.4 \% \\
22.6 \%\end{array}$ & $.001 *$ & $\begin{array}{l}40 \% \\
38.9 \% \\
21.1 \%\end{array}$ & $\begin{array}{l}53 \% \\
31.9 \% \\
15.1 \%\end{array}$ & .066 \\
\hline $\begin{array}{l}\text { Do you think that after } \\
\text { your COVID-19 } \\
\text { pandemic, you will be } \\
\text { more careful in your } \\
\text { standard measures } \\
\text { regarding } \\
\text { contamination in your } \\
\text { patients? }\end{array}$ & $\begin{array}{l}\text { Yes } \\
\text { No } \\
\text { Undecided }\end{array}$ & $\begin{array}{l}77.6 \% \\
4.8 \% \\
17.6 \%\end{array}$ & $\begin{array}{l}88.9 \% \\
1.6 \% \\
9.5 \%\end{array}$ & $.012^{*}$ & $\begin{array}{l}80.2 \% \\
3.7 \% \\
16.1 \%\end{array}$ & $\begin{array}{l}91.2 \% \\
1.7 \% \\
7.1 \%\end{array}$ & .033 \\
\hline
\end{tabular}




\begin{tabular}{|c|c|c|c|c|c|c|c|}
\hline $\begin{array}{l}\text { With the COVID-19 } \\
\text { outbreak, did you regret } \\
\text { that you chose the } \\
\text { dentistry profession? }\end{array}$ & $\begin{array}{l}\text { Yes } \\
\text { No } \\
\text { Undecided }\end{array}$ & $\begin{array}{l}9.7 \% \\
78.8 \% \\
11.5 \%\end{array}$ & $\begin{array}{l}8.9 \% \\
74.7 \% \\
16.4 \%\end{array}$ & .426 & $\begin{array}{l}7.9 \% \\
78.1 \% \\
14 \%\end{array}$ & $\begin{array}{l}12.4 \% \\
73.5 \% \\
14.2 \%\end{array}$ & .382 \\
\hline $\begin{array}{l}\text { Do antibiotics benefit in } \\
\text { the treatment of } \\
\text { COVID- } 19 \text { ? }\end{array}$ & $\begin{array}{l}\text { Yes } \\
\text { No } \\
\text { I don't } \\
\text { know }\end{array}$ & $\begin{array}{l}3.6 \% \\
83 \% \\
13.4 \%\end{array}$ & $\begin{array}{l}3.7 \% \\
77.4 \% \\
18.9 \%\end{array}$ & .357 & $\begin{array}{l}2.2 \% \\
76.4 \% \\
21.4 \%\end{array}$ & $\begin{array}{l}5.1 \% \\
83.5 \% \\
11.4 \%\end{array}$ & .133 \\
\hline $\begin{array}{l}\text { Can a mother diagnosed } \\
\text { with COVID-19 } \\
\text { breastfeed her child? }\end{array}$ & $\begin{array}{l}\text { Yes } \\
\text { No } \\
\text { I don't } \\
\text { know }\end{array}$ & $\begin{array}{l}15.2 \% \\
49.0 \% \\
35.8 \%\end{array}$ & $\begin{array}{l}12.1 \% \\
54.2 \% \\
33.7 \%\end{array}$ & .559 & $\begin{array}{l}11.6 \% \\
53.3 \% \\
35.1 \%\end{array}$ & $\begin{array}{l}14.7 \% \\
49 . \% \\
35.6 \%\end{array}$ & .285 \\
\hline
\end{tabular}

5

$6 *$ Chi-square test $\mathrm{p}<0.05$

7

8

9

10

11

12

13

14

15

16

17

18

19

20

21

22 


\section{Table 3(on next page)}

Table 3

Demonstrates in which internship students are more concerned about COVID-19 
1

2

3

4

5

6

7 Table 3: Demonstrates in which internship students are more concerned about COVID-19

\begin{tabular}{|l|l|l|l|}
\hline Internships & $\begin{array}{l}\text { Preclinical } \\
(\mathrm{n}=242) \%\end{array}$ & $\begin{array}{l}\text { Clinical } \\
(\mathrm{n}=113)\end{array}$ & P value \\
\hline $\begin{array}{l}\text { Oral and Maxillofacial } \\
\text { Surgery }\end{array}$ & $35.1 \%$ & $4.5 \%$ & \\
\hline $\begin{array}{l}\text { Endodontics } \\
\text { Periodontology }\end{array}$ & $24.8 \%$ & $40.7 \%$ & \\
\hline $\begin{array}{l}\text { Prosthodontic } \\
\text { Oral Diagnosis and }\end{array}$ & $14.5 \%$ & $16.8 \%$ & $.001^{*}$ \\
\hline $\begin{array}{l}\text { Radiology } \\
\text { Restorative dentistry }\end{array}$ & $6.1 \%$ & $23 \%$ & \\
\hline Pediatric Dentistry & $2.1 \%$ & $7.9 \%$ & \\
\hline Orthodontics & $1.7 \%$ & $7.1 \%$ & \\
\hline
\end{tabular}

8

$9 *$ Chi-square test $\mathrm{p}<0.05$

10

11

12

13

14

15 
Figure 1

Sources about information about COVID-19

Sources about information about COVID-19 


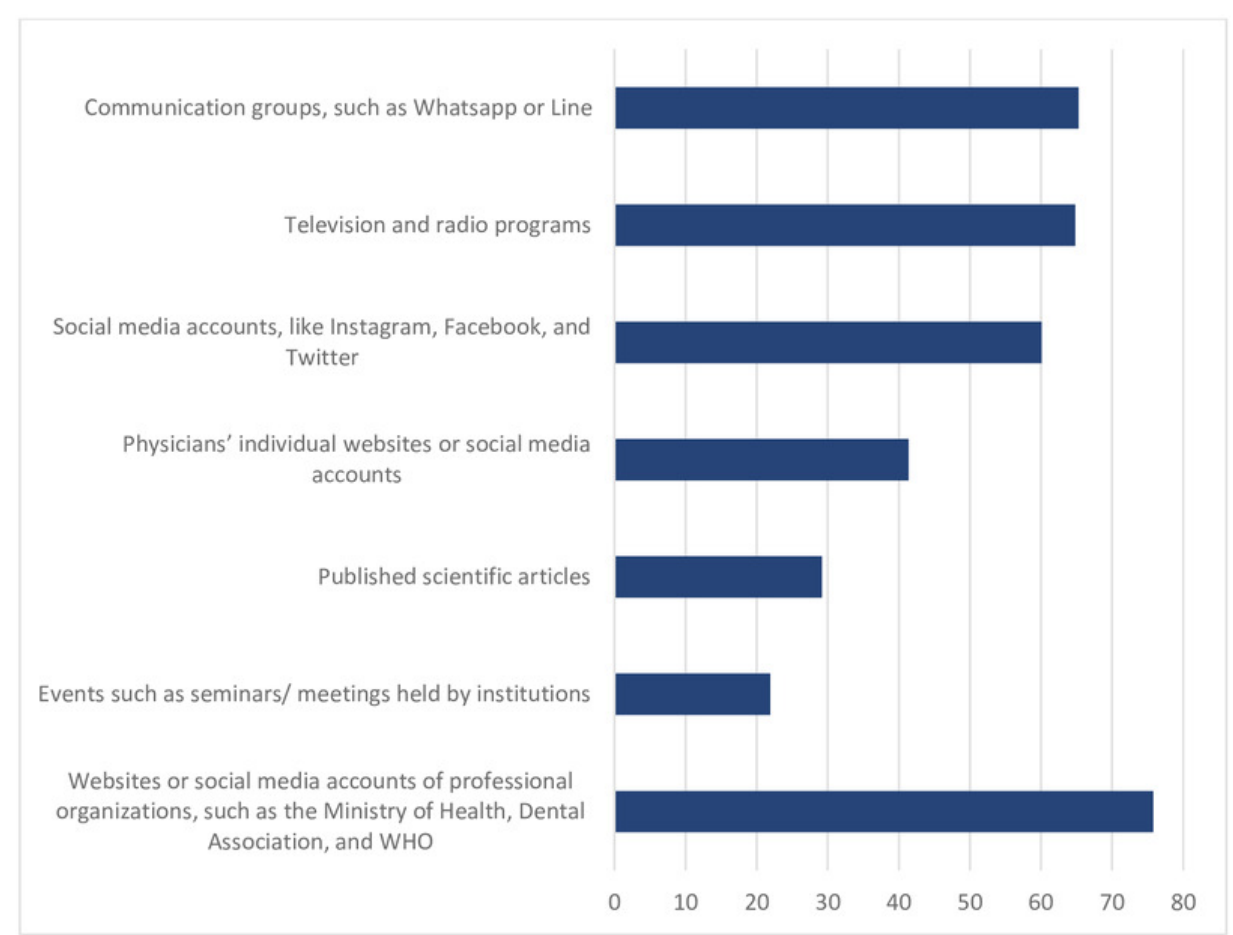


Figure 2

Individual measures taken by dental students against COVID-19 in their daily lives

Individual measures taken by dental students against COVID-19 in their daily lives 


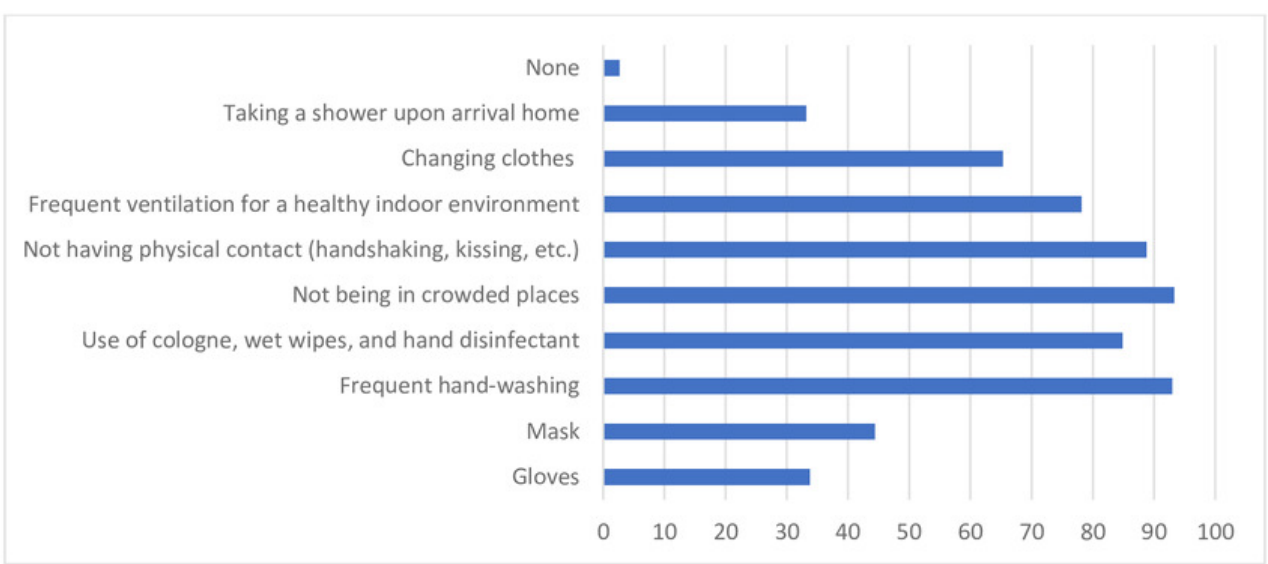


Figure 3

Precautions taken by clinical students for themselves in internships related to COVID-19

Precautions taken by clinical students for themselves in internships related to COVID-19 


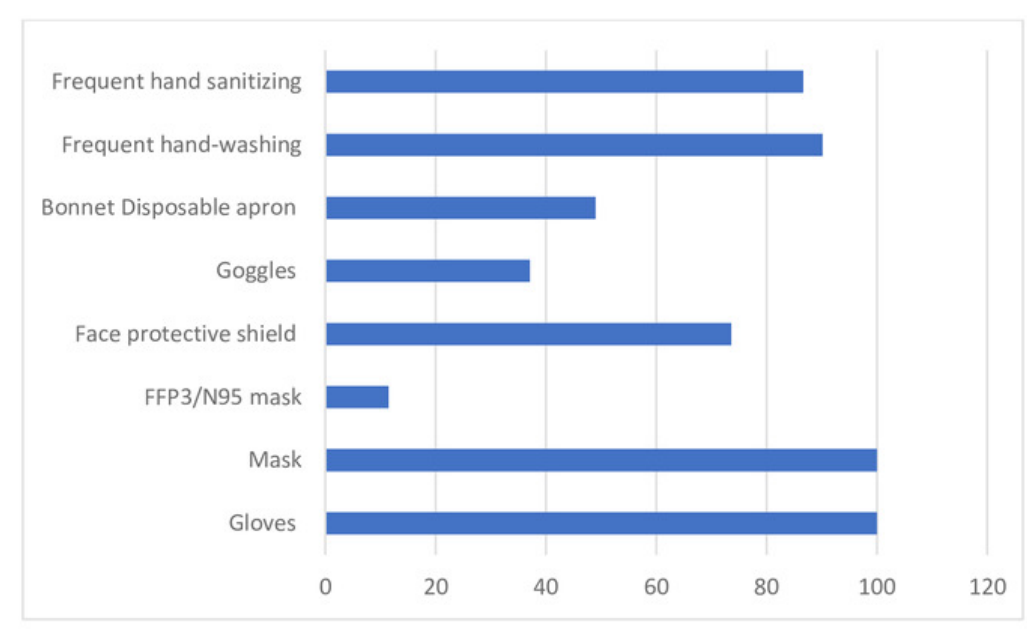


Figure 4

Precautions taken with the patient regarding COVID-19 while dental procedures

Precautions taken with the patient regarding COVID-19 while dental procedures 


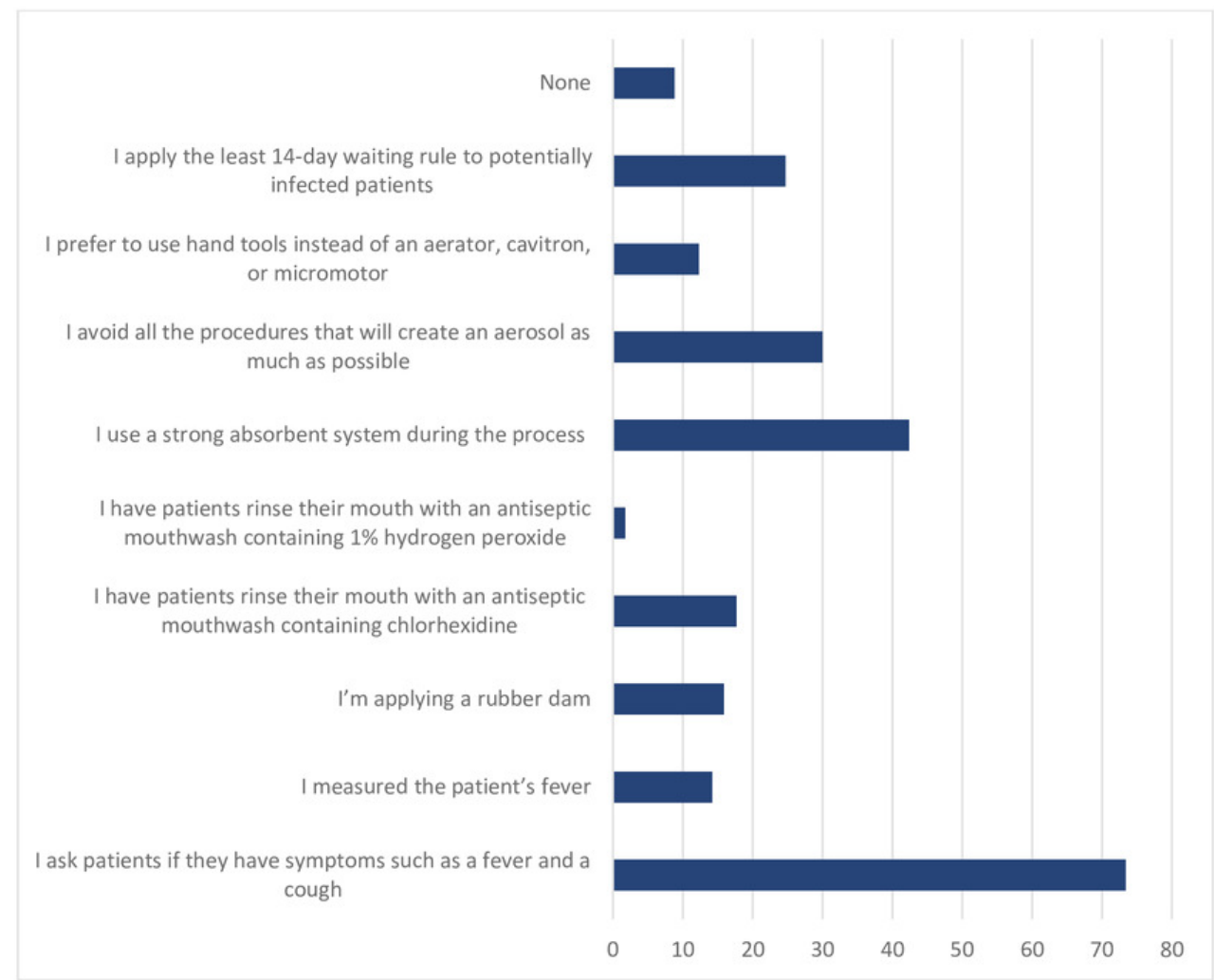

